\title{
Effectiveness Of Law Enforcement Implementation In Case of Middle Assistance Oriented On Restorative Justice
}

\author{
Moh. Suharto*) and Umar Ma'ruf**) \\ *) Police of Grobogan, E-mail: muhsuharto46@gmail.com \\ ${ }^{* *}$ Faculty of Law Universitas Islam Sultan Agung
}

\begin{abstract}
The purpose of this study was to determine the implementation of a restorative justice system in cases of mild persecution in the community which has not been effective at this time. The method used in this approach is sociological juridical. Restorative justice is an alternative settlement of criminal cases which in the criminal justice procedure mechanism focuses on punishment which is converted into a dialogue and mediation process that involves the perpetrator, victim, family of the perpetrator/victim, and other related parties to jointly create an agreement on the settlement of a criminal case that is fair and balanced for both the victim and the perpetrator by prioritizing restoration to its original state and restoring the pattern of good relations in society Case LP/B/06/II/2018/Central Java/Res. $\mathrm{Pbg} / \mathrm{Sec}$. fret, The victim was subjected to physical violence by the suspect. Based on the report, the Mrebet Police Chief processed and completed the investigation file. The police chief through his authority directs to the victim that the case can be resolved by restorative justice. Even though he had refused, the victim finally agreed to make peace with the suspect. This also happened in the Grobogan area, where Ulil as the persecutor and Surip who was the persecuted party were facilitated by the police to make peace through restorative justice. However, not all of the community, especially victims of mild persecution, are willing to carry out legal settlements in restorative justice, where Ulil as the persecutor and Surip who is the persecuted party are facilitated by the police to make peace through restorative justice. However, not all of the community, especially victims of mild persecution, are willing to carry out legal settlements in restorative justice.

Keywords: Restorative Justice; Mild Torture; System Implementation.
\end{abstract}

\section{Introduction}

Criminal Justice System or the Law Enforcement System as one of the subsystems of state administration in the context of criminal law enforcement. The Criminal Justice System is a sub-system of interrelated criminal justice including the police, prosecutors, courts, and correctional institutions with the aim of tackling crime. ${ }^{1}$ Tackling is defined as controlling crime so that it is within the limits of tolerance. ${ }^{2}$

The implementation of criminal justice is a process from the time the investigation is carried out until the court decision has the status of res judicata

\footnotetext{
${ }^{1}$ Mardjono Reksodipuro, Sistem Peradilan Pidana Indonesia: Melihat Kepada Kejahatan Dan Penegakan Hukum Dalam Batas- Batas Toleransi Jakarta: Fakultas Hukum Indonesia, 1993, p. 1.

2 Lilik Mulyadi, Kompilasi Hukum Pidana Dalam Prespektif Teoritik dan Praktik Peradilan, Bandung: Mandar Maju, 2007, p 5.
} 
(legally binding; inkracht van gewaijsde) or already has permanent legal force. ${ }^{3}$ In handling criminal acts, the Indonesian criminal justice system currently still uses a retributive justice system that is oriented towards revenge and places greater emphasis on legal certainty. If the handling of criminal acts (extra ordinary crimes, ordinary crimes, and light motives) is not distinguished, especially criminal acts whose losses are possible to be recovered, of course it can sacrifice a sense of justice and social reactions to victims. The victim here is not only a party who is harmed from a crime, but also a suspect as a victim of the criminal justice system that is not in accordance with the nature of the criminal objective, namely justice for both parties. In its application there has also been a buildup of cases, high costs, and even overcapacity in correctional institutions. Therefore, ${ }^{4}$

According to Soebekti, discretion is wisdom based on considerations of justice solely without being bound by the provisions of the law. ${ }^{5}$ Meanwhile, according to Satjipto Rahardjo, this discretionary authority is essentially contrary to the principle of the state based on legal certainty. However, an order in society that is completely based on law is also an ideal that cannot be achieved. Therefore, in fact, discretion is the completeness of the legal regulatory system itself. Furthermore, according to Skolnick, it is wrong to argue that discretion is simply equated with arbitrariness or doing what the police want. ${ }^{6}$

The police as one of the sub-systems of the criminal justice system have the task of law enforcement in optima forma. The police is a living law, because in the hands of the police the law can experience its manifestation. It contains a lot of human involvement as decision makers. Philosophical things in ordinary law are transformed into physical and human. ${ }^{7}$

The police are given the authority based on Article 7 Paragraph (1) point j of Act No. 8 of 1981 concerning the Criminal Procedure Code, Article 16 Paragraph (1) and Article 18 of Act No. 2 of 2002 concerning the Indonesian National Police in the form of, "may take other actions", with "certain conditions" or referred to as "discretion". With this authority, investigators can take discretionary action in the form of stopping, setting aside, or not taking action against a violation that has been determined by law. That is, investigators are required to choose with a policy how he should act. The authority that is in him based on official rules, is used as a justification for taking a wise way to approach the reality of his duties based on a moral, humanitarian and conscientious approach from formal provisions. ${ }^{8}$ The use of the article in question opens the door to the entry of alternative criminal settlement processes based on the concept of restorative justice.

\footnotetext{
${ }^{3}$ Anas Yusuf, Implementasi Restorative Justice Dalam Penegakan Hukum Oleh Polri Demi Mewujudkan Keadilan Substantif, Jakarta: Penerbit Universitas Tri Sakti, 2016, p. 3.

${ }^{4}$ M. Faal, Penyaringan Perkara Pidana Oleh Polisi (Diskresi Kepolisian), Jakarta: Pradnya Paramita, 1991, p. 3.

${ }^{5}$ R. Soebekti, Kamus Hukum, Jakarta: Pradnya Paramita, 1980, p. 4.

${ }^{6}$ Satjipto Raharjdo, Op. Cit, p. 111.

${ }^{7}$ Satjipto Raharjdo, Masalah Penegakan Hukum: Suatu Tinjauan Sosiologis, Bandung: CV Sinar Baru, 1991, p. 95.

${ }^{8}$ Mahrus Ali, Sistem Peradilan Pidana Progresif; Alternatif Dalam Penegakan Hukum Pidana, Yogyakarta: FH UII, Jurnal Hukum, No. 2 Vol. 14, 2007, p. 221.
} 
The issuance of PERKAP No. 14 of 2012 concerning Management of Criminal Investigations jo. The Chief of Police Circular No.: SE/8/VIII/2018 concerning the Application of Restorative Justice in the Settlement of Criminal Cases states that the implementation of the authority to investigate and/or investigate criminal acts by Polri Investigators who apply the principle of restorative justice in their investigative methods is based on the provisions KUHAP and provisions in Act No. 2/2002 on the NRI Police.

The concept of restorative justice is an approach model in efforts to resolve legal violations that occur by bringing the interests of victims and perpetrators together to sit in a meeting to talk together in the process of resolving criminal cases. ${ }^{9}$ The restorative justice approach is assumed to be a model and mechanism that works outside the criminal justice system to deal with problems within the criminal justice system itself and current criminal cases. ${ }^{10}$

If the concept of restorative justice is applied in the law enforcement process, it is possible to answer the various disappointments of law enforcement so far which have not yet reflected the principle of justice as a legal goal. The handling of criminal cases is mainly the perpetrators of criminal acts whose losses do not harm the state, instead they are processed, prosecuted, and sentenced in court. In fact, according to the community, criminal cases with small losses are not feasible to be resolved in court. 11

Restorative justice is an alternative settlement of criminal cases which in the criminal justice procedure mechanism focuses on punishment which is converted into a dialogue and mediation process that involves the perpetrator, victim, family of the perpetrator/victim, and other related parties to jointly create an agreement on the settlement of a criminal case that is fair and balanced for both the victim and the perpetrator by prioritizing restoration to its original state and restoring the pattern of good relations in society

The purpose of holding this restorative justice is to reform the criminal justice system which still prioritizes prison criminal law. The development of the criminal system is no longer based on the perpetrator but has led to the alignment of the interests of the victim's recovery and the accountability of the perpetrators of criminal acts. ${ }^{12}$

The basic principle of restorative justice is the existence of restoration to victims who suffer as a result of crime by providing compensation to victims, peace, perpetrators doing social work or other agreements. A fair law in restorative justice is certainly not one-sided, impartial, not arbitrary, and only sided with the truth in accordance with applicable laws and regulations and considers equal rights to compensation and balance in every aspect of life. Perpetrators have the opportunity to be involved in restoring the situation

\footnotetext{
${ }^{9}$ Marlina, Peradilan Pidana Anak di Indonesia, Bandung: Refika Aditama, 2009, p. 180.

${ }^{10}$ Khairul Saleh Amin, Perkernbangan Sistem Peradilan Pidana di Indonesia, Jakarta: Pamator Press, 2010, p. 90.

${ }^{11}$ Anas Yusuf, Op. Cit, p. 19.

${ }^{12}$ https://badilum.mahkamahagung.go.id/index.php?option=com attachments\&task=download\&id =811, accessed on 17 April 2021.
} 
(restoration), the community plays a role in preserving peace and the courts play a role in maintaining order. ${ }^{13}$

Criminal cases that can be resolved with restorative justice are cases of minor crimes with criminal threats as regulated in 364, 373, 379, 384, 407 and Article 482 of the Criminal Code with a loss value of not more than IDR 2,500,000, (two million five hundred rupiah), women's cases dealing with the law, children's cases and narcotics cases.

Apart from the minor crimes mentioned above, for example, the handling of criminal acts of persecution Article 351 Paragraph (1) of the Criminal Code with No. Case LP/B/06/II/2018/Central Java/Res. Pbg/Sec. More importantly, the victim was physically abused by the suspect. Based on the report, the Mrebet Police Chief processed and completed the investigation file. The police chief through his authority directs to the victim that the case can be resolved by restorative justice. Even though he had refused, the victim finally agreed to make peace with the suspect. This also happened in the Grobogan area, where Ulil as the persecutor and Surip who was the persecuted party were facilitated by the police to make peace through restorative justice. ${ }^{14}$

This shows that the crime of persecution is one of the crimes that can be resolved by restorative justice by the parties. Restorative justice is a case settlement that focuses on the direct participation of perpetrators, victims, and the community. Not all criminal acts must be pursued through the trial process. Prioritizing peace through deliberation to reach consensus is an integral mechanism in people's lives in Indonesia. The purpose of this paper is to determine and analyze the effectiveness of implementing law enforcement in cases of minor maltreatment oriented to restorative justice.

\section{Research Methods}

The type of research used in this study is a descriptive analytical legal research type. The type of approach in this writing is sociological juridical. Methods of data collection using literature study, field observations, and interviews. The data processing method is carried out qualitatively.

\section{Result and Discussion}

\subsection{Implementation of a Restorative Justice System in Cases of Mild Abuse}

Restorative justice efforts carried out by investigators as an effort to resolve criminal acts of persecution based on discretionary authority in accordance with the provisions of Article 16 paragraph (1) letter L jo. Article 18 of Act No. 2 of 2002 concerning the National Police jo. Article 69 letter b Perkap No. 14/2012 concerning Investigation Management jo. Chief of Police Circular No: SE/8/VIII/2018 concerning the Application of Restorative Justice in the Settlement

\footnotetext{
13 Ibid.

14 Surip, Personal Interview with Victims of Minor Persecution in the Karangrayung Area, Grobogan, Interview on 12 May 2021.
} 
of Criminal Cases. ${ }^{15}$ Based on the Circular, acts of persecution are classified as cases that can be carried out by restorative justice efforts. In addition to the existing formal provisions, investigators have several material considerations with reference to the provisions of the Circular, including: 16

- Considering the law enforcement process through restorative justice is a good thing because the principle is win-win solutions and the resolution is fast. Coupled with looking at the psychology of the community in the area as well as the consideration to fulfill the community's sense of justice;

- Settlement by restorative justice by prioritizing the principle of expediency and legal justice, not a legal certainty approach, is carried out selflessly and solely for justice and without compensation;

- The restorative justice process stated that the real reason was substantial, namely how law enforcement efforts can guide the community through a mediation process so that they do not commit unlawful acts;

- Investigators use Article 16 paragraph (1) letter L jo. Article 18 of Act No. 2 of 2002 concerning the National Police, namely "in the public interest to take action on their own judgment" based on consideration of the benefits and risks of such action.

According to investigators, the authority of the police to act on their own judgment is very difficult to measure the limits. However, in this case of persecution, the investigator judges that it is appropriate to carry out restorative justice efforts. Restorative justice efforts that are usually taken by Grobogan Police investigators use two models, namely the Victim-Offenders Mediation model and the Family and Community Group Conferences.

The Victim-Offenders Mediation model is a settlement model that involves several parties who meet in the process of implementing restorative justice, namely the victim, the perpetrator of the crime, and the families of the two litigants and the investigator as a mediator. Although the locus of the incident is in the Grobogan Police area, this model is applied if the victim and perpetrator are not citizens of Grobogan. If the victim and perpetrator are residents of the Grobogan sub-district, use the Family and Community Group Conferences model. This settlement model involves victims, perpetrators, and their families as well as community leaders who are seen as having an important role in reducing social turmoil that arises in society. ${ }^{17}$

Restorative justice efforts implemented by the Grobogan Police investigators have several steps. First, the investigator directed both parties to make a Peace Request Letter. Second, investigators provide an understanding of the important benefits of restorative justice, namely the maintenance of family

\footnotetext{
${ }^{15}$ Ibnu Suka, Gunarto, and Umar Ma'ruf, Peran Dan Tanggung Jawab Polri Sebagai Penegak Hukum Dalam Melaksanaan Restorative Justice Untuk Keadilan Dan Kemanfaatan Masyarakat, Jurnal Hukum Khaira Ummah Vol. 13. No. 1 March 2018, p. 115-116.

${ }^{16}$ Oscar Stefanus Setjo and Umar Ma'ruf, Investigation of Children Which Conflicting With Law in Narcotics Criminal Acts In Law Area of the Semarang City Police Jurisdiction, Jurnal Daulat Hukum Volume 3 Issue 2, June 2020, p. 287-288.

${ }^{17}$ Arif Septria Hendra Saputra, Gunarto, and Lathifah Hanim, Penerapan Restoratife Justice Sebagai Alternatif Penyelesaian Tindak Pidana Penganiayaan Di Satreskrim Polsek Lasem, Jurnal Daulat Hukum Vol. 1. No.1 2018, p. 159.
} 
relations between parties, especially if they are neighbors. Third, the investigator directed the victim, represented by his father as the 1st Party and the suspect as the 2nd Party, to make a Memorandum of Understanding with the following contents:

- The 2nd Party admits to having abused the 1st Party's children;

- The second party regrets his actions;

- The second party apologizes to the first party and the second party forgives the second party;

- The 2nd Party promises not to commit any criminal acts of abuse to the 1st Party's children or other people;

- If the Second Party repeats it, it can be prosecuted according to the applicable law in Indonesia;

- After making this Agreement, there are no problems between the two parties.

After that, both parties signed the letter in the presence of community leaders and the family of the second party. The final stage is that investigators compile administrative completeness and special case title documents and report on the results of the case title. In the Chief of Police Circular No.: SE/8/VIII/2018 concerning the Application of Restorative Justice in the Settlement of Criminal Cases after the final stage, the investigator issues Decree SP3 (Warrant for Termination of Investigation) signed by the Head of Police and recorded in the register as restorative justice cases are counted as case settlements. However, in this case the investigator did not issue the SP3 because the investigator had not sent the SPDP to the public prosecutor or the reported and the reporter, as in Article 109 paragraph (1) of the Criminal Procedure Code which states that,

In the Circular of the Chief of Police, restorative justice can only be done once. If the perpetrator repeats any crime, it will be processed according to the laws and regulations. Investigators attach a record of evidence of a restorative justice statement as evidence of the judge's consideration letter in deciding the case. The existence of the Chief of Police Circular provides an opportunity for investigators to make legal breakthroughs in resolving criminal acts of persecution with the concept of restorative justice. In the Circular, investigators can only carry out restorative justice efforts if both parties request to be reconciled. However, ${ }^{18}$

\subsection{Factors Affecting the Implementation of a Restorative Justice System in Cases of Mild Abuse}

The success of restorative justice efforts depends on the parties. Of course, there are many differences in the conditions and motivations of the parties in the process, for example the victim's orientation seeks justice that justice must imprison the suspect. This is inversely proportional to the mechanism offered by restorative justice which is more oriented to the quality of the process, namely making criminals aware of their mistakes, solving conflict needs, calming victims

\footnotetext{
18Sarwadi and Bambang Tri Bawono, Restorative Justice Approach in Diversion System for Settlement of Criminal Cases for Children in Indonesia, Jurnal Daulat Hukum Volume 3 Issue 4, December 2020, p. 377-400.
} 
from fear and so on. Here are some restorative justice problems based on the parties:

- Victim

It must be acknowledged that some of the victims in these cases may not want restorative justice for various reasons. It is important that victims should not be forced to participate in the restorative justice process. However, investigators can try to provide a legal opinion about their right to participate in the restorative justice process at any time. In cases involving child victims, special care must be taken to protect and ensure that their consent is completely voluntary. In some recovery processes that involve child victims, or other vulnerable groups (eg women, or individuals with mental disorders), investigators or their legal advisors provide understanding to victims with a clear goal of participating in restorative justice.

- Perpetrator

The most important thing for a restorative justice effort is that the perpetrator is able to fulfill the commitments he has made as part of the agreement. Offenders must demonstrate that they have accepted responsibility for their behavior and are prepared to take responsibility for it in a very tangible and practical way.

- Investigator

In addition to the parties above, the issue of discretion in the form of restorative justice is the central point of the investigator's opinion or belief in the problems at hand. The problems faced are inseparable from the community. If the investigator considers that the people they are facing are citizens who must be protected, nurtured, protected, guided or served, the tendency for restorative justice will be greater. This is because investigators are aware that their task is not solely to take repressive measures, such as those who carry out illegal logging. In this case, the perpetrator carried out a mild persecution so that investigators could carry out restorative justice efforts so that they did not have to take action in the SPP process.

On the other hand, if the investigator considers the community as an opponent, as well as the community considers the investigator as an enemy, then the relationship between the two becomes less good and always suspicious. ${ }^{19}$ In the case of investigators suggesting that the case be resolved peacefully to the parties, the public often perceives it as a trick by the police to obtain material benefits. These assumptions canaffect the efforts to implement this restorative justice. According to Achmad Ali, this happened because the socialization was not optimal to the target of the rule of law, namely the community. ${ }^{20}$

Law enforcement against the rule of law is not limited to arresting as many perpetrators as possible for formal processing. However, what is more substantial is how law enforcement efforts can guide the community not to commit acts that

\footnotetext{
${ }^{19}$ Malik AL-Ghazali, Restorative Justice Approach on The Under Age (Minors) Violator of The Traffic Case Accident (Laka) That Lead to Death in Polres Majalengka, Jurnal Daulat Hukum Volume 1 Issue 3 September 2018, p. 708-800.

${ }^{20}$ Ragil Tri Wibowo and Akhmad Khisni, Restorative Justice in Application for Crime Investigation on Property, Jurnal Daulat Hukum Volume 1 No. 2 June 2018, p. 555-556.
} 
violate the law. In the context of law enforcement, the police as investigators can act to mobilize community participation in the democratic law enforcement process. $^{21}$

In addition to some of the factors above that affect the problematic implementation of restorative justice is a cultural factor. Culture as according to Soerjono Soekanto, what is meant by culture is one element of the legal system, in the form of values that underlie the enactment of a law. These values are abstract conceptions of what is considered good (so adopted) and what is considered bad (so avoided). ${ }^{22}$

Associated with restorative justice investigators of the Grobogan Police, namely the values of order and peace are things that attract attention. Investigators must be able to resolve these elements. Order is more emphasized on the public interest while peace is more focused on the interests of the parties. Likewise, the harmony between traditional values and renewal values so as not to cause turmoil. As a result, the overall values that exist in society also influence the actions of investigators, including in terms of the implementation of restorative justice.

\section{Closing}

Restorative justice is very much needed to be an option for the settlement of criminal acts in the context of overcoming criminal acts of persecution or other criminal acts, including crime prevention. Judging from the basic concept and objectives, it can be said that restorative justice has a strategic value that can cover the shortcomings of the current conventional criminal justice system. In fact, the system is often considered to be lacking in providing legal solutions, so it is very relevant if restorative justice is proposed to be a part of the criminal law system in Indonesia.

\section{References}

\section{Journal}

[1] Arif Septria Hendra Saputra, Gunarto, dan Lathifah Hanim, Penerapan Restoratife Justice Sebagai Alternatif Penyelesaian Tindak Pidana Penganiayaan Di Satreskrim Polsek Lasem, Jurnal Daulat Hukum Vol. 1. No. 1 March 2018

[2] Ibnu Suka, Gunarto, dan Umar Ma'ruf, Peran Dan Tanggung Jawab Polri Sebagai Penegak Hukum Dalam Melaksanaan Restorative Justice Untuk Keadilan Dan Kemanfaatan Masyarakat, Jurnal Hukum Khaira Ummah Vol. 13. No. 1 March 2018

\footnotetext{
${ }^{21}$ Iman Faturrahman and Bambang Tri Bawono, Application of Restorative Justice to Solution of Traffic Accidents, Jurnal Daulat Hukum Volume 4 Issue 1, March 2021, p. 30-31.

${ }^{22} \mathrm{M}$. Gargarin Friyandi and Aryani Witasari, Restorative Justice In Application For Crime Investigation Abuse In Polsek Middle Semarang, Jurnal Daulat Hukum Volume 2 Issue 1, March 2019, p. 41-44.
} 
[3] M.Gargarin Friyandi dan Aryani Witasari, Restorative Justice In Application For Crime Investigation Abuse In Polsek Middle Semarang, Jurnal Daulat Hukum Volume 2 Issue 1, March 2019

[4] Mahrus Ali, Sistem Peradilan Pidana Progresif; Alternatif Dalam Penegakan Hukum Pidana, Yogyakarta: FH UII, Jurnal Hukum, No. 2 Vol. 14, 2007

[5] Malik AL-Ghazali, Restorative Justice Approach on The Under Age (Minors) Violator of The Traffic Case Accident (Laka) That Lead to Death in Polres Majalengka, Jurnal Daulat Hukum Volume 1 Issue 3 September 2018

[6] Oscar Stefanus Setjo dan Umar Ma'ruf, Investigation of Children Which Conflicting With Law in Narcotics Criminal Acts In Law Area of the Semarang City Police Jurisdiction, Jurnal Daulat Hukum Volume 3 Issue 2, June 2020

[7] Ragil Tri Wibowo dan Akhmad Khisni, Restorative Justice in Application for Crime Investigation on Property, Jurnal Daulat Hukum Volume 1 No. 2 June 2018

[8] Sarwadi dan Bambang Tri Bawono, Restorative Justice Approach in Diversion System for Settlement of Criminal Cases for Children in Indonesia, Jurnal Daulat Hukum Volume 3 Issue 4, December 2020

\section{Books}

[1] Anas Yusuf, Implementasi Restorative Justice Dalam Penegakan Hukum Oleh Polri Demi Mewujudkan Keadilan Substantif, Jakarta: Penerbit Universitas Tri Sakti, 2016

[2] Iman Faturrahman dan Bambang Tri Bawono, Application of Restorative Justice to Solution of Traffic Accidents, Jurnal Daulat Hukum Volume 4 Issue 1, March 2021

[3] Khairul Saleh Amin, Perkernbangan Sistem Peradilan Pidana di Indonesia, Jakarta: Pamator Press, 2010

[4] Lilik Mulyadi, Kompilasi Hukum Pidana Dalam Prespektif Teoritik dan Praktik Peradilan, Bandung: Mandar Maju, 2007

[5] Mardjono Reksodipuro, Sistem Peradilan Pidana Indonesia: Melihat Kepada Kejahatan Dan Penegakan Hukum Dalam Batas- Batas Toleransi JJakarta: Fakultas Hukum Indonesia, 1993

[6] M. Faal, Penyaringan Perkara Pidana Oleh Polisi (Diskresi Kepolisian), Jakarta: Pradnya Paramita, 1991

[7] Marlina, Peradilan Pidana Anak di Indonesia, Bandung: Refika Aditama, 2009

[8] R. Soebekti, Kamus Hukum, Jakarta: Pradnya Paramita, 1980

[9] Satjipto Raharjdo, Masalah Penegakan Hukum: Suatu Tinjauan Sosiologis, Bandung: CV Sinar Baru, 1991

\section{Internet}

[1] https://badilum.mahkamahagung.go.id/index.php?option=com attachments \&task=download\&id=811, accessed on 17 April 2021.

\section{Interview}

[2] Surip, Personal Interview with Victims of Minor Persecution in the Karangrayung Area, Grobogan, Interview on 12 May 2021. 